\title{
Evaluation of the Response of Sorghum to Tillage Systems and Nitrogen Fertilization
}

\author{
Marwan Ramadhan $(\mathbb{D}$ and Sadiq Muhsin $(\mathbb{D}$ \\ Department of Agric. Machines and Equipment, College of Agriculture, University of Basrah, Basra, Iraq \\ Correspondence should be addressed to Marwan Ramadhan; ramadhanalali0@gmail.com
}

Received 8 December 2020; Accepted 16 February 2021; Published 22 February 2021

Academic Editor: Vera Popovic

Copyright ( 2021 Marwan Ramadhan and Sadiq Muhsin. This is an open access article distributed under the Creative Commons Attribution License, which permits unrestricted use, distribution, and reproduction in any medium, provided the original work is properly cited.

\begin{abstract}
In the subtropical semi-arid zones, sorghum Sorghum bicolor (L.) productivity is limited by numerous constraints. Relatively few studies have been conducted to measure the response of grain sorghum varieties to tillage and nitrogen. For sustainable crop production, selected tillage practice and fertilizer application are important. Field experiments were conducted at Al Qurna (QL), $74 \mathrm{~km}$ northwest Basrah province and Shatt al-Arab (SHL) and $17 \mathrm{~km}$ east Basrah province. A randomized complete block design, arranged in a split-split plot, was used with three replications. The tillage system was no tillage (NT), reduced tillage (RT), and conventional tillage (CT), while sorghum varieties were Inqadh, Rabih, and Cavire 2, and four levels of $\mathrm{N}$ fertilizer, viz., $0,40,80$, and $120 \mathrm{~kg} \mathrm{ha}^{-1}$. The objective of research was to evaluate two sorghum (Sorghum bicolor L.) varieties to tillage system and nitrogen $(\mathrm{N})$ fertilizer. The application of tillage was shown to enhance the growth of sorghum as observed in the plant height, leaf area, number of grains panicle ${ }^{-1}, 1000$-grain weight, yield, biomass yield, and root dry matter. CT surpassed the other treatments for all studied traits. The highest value of plant height, number of grains panicle ${ }^{-1}$, grain yield, biomass yield, and root dry matter in the QL and SHL locations, respectively, were produced by Cavire 2. The plots fertilized with $120 \mathrm{~kg} \mathrm{~N}^{-1}$ maximize the values of plant height $\left(132.33 \mathrm{~cm}\right.$ in the SHL location), leaf area (3040.53 and $2751.47 \mathrm{~cm}^{2}$ in the QL and SHL location respectively), number of grains panicle ${ }^{-1}$ (1431.37 in the SHL location), 1000 -grain weight ( $31.77 \mathrm{~g}$ in the QL location), biomass yield $\left(15752.00 \mathrm{~kg} \mathrm{ha}^{-1}\right.$ in the SHL location), and root dry matter $\left(22.42\right.$ and $20.75 \mathrm{~g}$ root cm$^{-3}$ in the QL and SHL locations, respectively). Cavire 2 variety under CT with $80 \mathrm{~kg} \mathrm{~N} \mathrm{ha}^{-1}$ in the QL location was the best (observed as the most promising) in terms of grain yield. Whereas Cavire 2 under CT showed best performance with $120 \mathrm{~kg} \mathrm{~N} \mathrm{ha}^{-1}$ in the QL location in terms of biomass yield character.
\end{abstract}

\section{Introduction}

The worthwhile production of sorghum depends on the appropriate inputs and better methods of agronomy and tillage. Tillage refers to the manipulation of soil in a physical manner. Conventional tillage (CT) implies intensive tillage with multiple tillage equipment passes to achieve seed sowing through land preparation. By changing soil bulk density and soil moisture content, conventional tillage practices cause changes in soil structure. Conventional tillage is also helpful in breaking the plough pan, enhancing infiltration. The decomposition of organic matter is subsequently improved, and mineral nutrients are readily available for crop growth [1]. Intensive soil manipulation, use of energy resources, lack of sustainability, and environmental vulnerabilities are also included [2]. Conservation tillage addresses the minimal manipulation of soil thus leaving stubbles on the surface of the soil from previous crops. Stubbles are also often buried in the soil, which is useful for augment the organic matter content. For timely cultivation of crops, conservation tillage is favored since it reduces costs, improves soil aggregate stability, and makes durable footing for environmental security. The method is economically reasonable, environmentally sound, and sustainable [3]. Notillage is a form of conservation tillage and is an extreme method of reduced tillage, where in the absence of any tillage practice, sorghum is planted in a narrow slot sufficient to cover the desired crop seed. In addition, no-tillage lowers the 
TABLE 1: Soil chemical and physical properties.

\begin{tabular}{|c|c|c|}
\hline \multirow{2}{*}{ Properties } & \multicolumn{2}{|c|}{ Sample value } \\
\hline & QL location & SHL location \\
\hline Soil texture & Silty clay & Silty clay \\
\hline Sand $(\%)$ & 9.2 & 5.2 \\
\hline Silt (\%) & 48.5 & 46.09 \\
\hline Clay (\%) & 42.3 & 48.7 \\
\hline $\mathrm{Ec}_{\mathrm{e}}\left(\mathrm{dS} \mathrm{m}^{-1}\right)$ & 8.72 & 6.48 \\
\hline $\mathrm{pH}$ & 7.25 & 7.17 \\
\hline Available N (ppm) & 42 & 38 \\
\hline Available P (ppm) & 13.36 & 7.91 \\
\hline Available K (ppm) & 61.4 & 123.5 \\
\hline Soluble $\mathrm{K}^{+}\left(\mathrm{m} \mathrm{Eq} \mathrm{L}^{-1}\right)$ & 3.61 & 4.93 \\
\hline Soluble $\mathrm{Na}^{+}\left(\mathrm{m} \mathrm{Eq} \mathrm{L}{ }^{-1}\right)$ & 30.32 & 32.1 \\
\hline Soluble $\mathrm{Ca}_{2}^{+}\left(\mathrm{m} \mathrm{Eq} \mathrm{L}^{-1}\right)$ & 25 & 24 \\
\hline Soluble $\mathrm{Mg}_{2}{ }^{+}\left(\mathrm{m} \mathrm{Eq} \mathrm{L}^{-1}\right)$ & 22 & 19 \\
\hline $\mathrm{Cl}^{-}\left(\mathrm{m} \mathrm{Eq} \mathrm{L}^{-1}\right)$ & 54 & 51 \\
\hline $\mathrm{CaCO}_{3}^{-}(\%)$ & 23.7 & 21.7 \\
\hline $\mathrm{HCO}_{3}^{-}\left(\mathrm{m} \mathrm{Eq} \mathrm{L}^{-1}\right)$ & 1.9 & 2.4 \\
\hline O. M. (\%) & 0.94 & 0.76 \\
\hline
\end{tabular}

field activities, reducing the cost of job input, energy, and other equipment.

Inadequate and imbalanced application of fertilization to crops not only leads to low crop yields but also decreases soil quality [4]. In crop production, nitrogen is the nutrient that is most limited. Its use is more efficient than any other input for rising food production. However, higher amounts of nitrogen can cause environmental problems, such as nitrate leaching, excessive nutrients in any water body, and greenhouse gas emissions [5]. Consequently, the proper use of nitrogen is essential for growing crop yield and reducing environmental harm.

Investigations on the performance of sorghum varieties in relation to the tillage system under different nitrogen fertilization levels for the current area have not been conducted. However, for better understanding, the evaluation of sorghum varieties would lead to selection of the most adoptable variety under various tillage and nitrogen management. Therefore, the aim of this experiment was to evaluate of the effects of various tillage systems and nitrogen fertilizer levels on the productivity of sorghum varieties.

\section{Materials and Methods}

2.1. Experimental Characterization of Soil. By using a soil auger up to $60 \mathrm{~cm}$, soil samples were collected from the experimental site from every location for soil characterization. A composite soil sample was collected in a clean plastic container after combining the soil samples. The composite soil sample was then air-dried and sieved $(2 \mathrm{~mm})$, and physicochemical properties were characterized (Table 1). The Bouyoucos hydrometer technique was used to obtain soil texture [6]. An automated $\mathrm{pH}$ meter was used to measure the $\mathrm{pH}$ of the experimental soil (model: Orion 701, Orion Manufacturing, MI, USA). The Kjeldahl method defined by Bremner was used to calculate total $\mathrm{N}$ [7]. Available soil phosphorus was measured by the method in [8].
TABle 2: Mean monthly rainfall, maximum and minimum temperatures, and humidity at QL and SHL locations during the experimental trial.

\begin{tabular}{lcccccccc}
\hline & \multicolumn{3}{c}{ SHL location } & \multicolumn{4}{c}{ QL location } \\
Month & $\mathrm{R}$ & $\mathrm{TM}$ & $\mathrm{Tm}$ & $\mathrm{Hm}$ & $\mathrm{R}$ & $\mathrm{TM}$ & $\mathrm{Tm}$ & $\mathrm{Hm}<$ \\
& $\mathrm{mm}$ & $\mathrm{C}^{\circ}$ & $\mathrm{C}^{\circ}$ & $\%$ & $\mathrm{~mm}$ & $\mathrm{C}^{\circ}$ & $\mathrm{C}^{\circ}$ & $\%$ \\
\hline Jul & - & 46.33 & 29.45 & 7.39 & - & 46.87 & 30.00 & 5.79 \\
Aug & - & 45.08 & 27.95 & 7.60 & - & 45.46 & 26.51 & 9.00 \\
Sep & - & 43.23 & 25.91 & 9.55 & - & 42.34 & 25.91 & 11.80 \\
Oct & - & 37.9 & 20.16 & 4.26 & - & 37.76 & 21.44 & 5.9 \\
Nov & 13.2 & 31.24 & 12.58 & 25.91 & 58.0 & 30.96 & 12.19 & 24.87 \\
\hline
\end{tabular}

R: rainfall, TM: maximum temperature, Tm: minimum temperature, and Hm: humidity.

At the tasseling stage (VT), soil bulk density of experimental soil was calculated. For each sampling location, soil cores by the core method [9] were taken at $(0-10,10-20$, 20-30, and 30-40 cm) depths. Three samples were selected randomly for measurements.

Parameters related to soil porosity were calculated from bulk density values and particle density [10] using the following equation:

$$
P=\left(1-\frac{\rho b}{\rho s}\right) \times 100
$$

where $P$ is the total porosity (\%), $\rho b$ is the bulk density $\left(\mathrm{g} \mathrm{cm}^{-3}\right)$, and $\rho s=2.65\left(\mathrm{~g} \mathrm{~cm}^{-3}\right)$ is the particle density. The average monthly rainfall, temperature, and humidity at QL and SHL locations during the experimental trial are shown in Table 2.

\subsection{Experimental Treatments, Design, and Crop Management.} The experiment was set up according to the randomized complete block design with split-split plot arrangement with three tillage practices, viz., no tillage, reduced tillage, and conventional tillage as the main plot factor, four levels of $\mathrm{N}$ fertilizer, viz., $0,40,80$, and $120 \mathrm{~kg} \mathrm{ha}^{-1}$ as subplot factor, and three local sorghum varieties, i.e., Inqadh, Rabih, and Cavire 2 as sub-sub-plots. The experiment had three replications in the QL and SHL locations.

No tillage system was a strict slot plant, while reduced tillage was done by two orthogonal ploughing using chisel plow followed by planking. Conventional tillage ploughing by moldboard plow was followed by planking. The source of nitrogen fertilizer was urea $46 \% \mathrm{~N}$. Urea was side dressed 4 weeks after planting.

The plot size was $4 \mathrm{~m} \times 3 \mathrm{~m}$. One-meter distance was maintained among plots within replication and $1.5 \mathrm{~m}$ distance between replications. Sowing was done manually by hand maintaining interrow spacing of $45 \mathrm{~cm}$ [11] and in-row spacing of $25 \mathrm{~cm}$. Sorghum was planted on July 10, 2020 . Three seeds were placed in each hole. After three weeks from sowing, the thinning process was started; in each hole, one plant was left. Via repeated hand and hoe weeding during the cropping season, experimental units were kept free of weeds. The first irrigation was applied immediately after sowing. The other irrigation intervals were done according to plant requirement. 
Phosphorus and potassium both were applied at $40 \mathrm{~kg}$ P. ha ${ }^{-1}$ through triple super phosphate $\left(46 \% \mathrm{P}_{2} \mathrm{O}_{5}\right)$ and at $54 \mathrm{~kg} \mathrm{~K} \mathrm{ha}{ }^{-1}$ through potassium sulphate $\left(48 \% \mathrm{~K}_{2} \mathrm{O}\right)$, respectively.

2.3. Measurements. Grain sorghum was harvested after physiological maturity from ten randomly selected central rows of plants from each experimental unit. Plant height, leaf area $\left(\mathrm{cm}^{2}\right)$, number of grains per panicle, weight of 1000 grains, grain yield per unit area, yield of biomass, and density of root mass were determined. Reported grain yields were corrected to $15 \%$ moisture for grain sorghum. 1000 grains randomly selected from the sub-sub-plot were weighed and recorded. Leaf area was calculated by using the following formula [12]:

$$
\text { leaf area }\left(\mathrm{cm}^{2}\right)=\text { maximum leaf width }(\mathrm{cm}) \times \text { maximum leaf length }(\mathrm{cm}) \times 0.75 \text {. }
$$

Root sampling, at tasseling stage, was performed [13]. A soil block that surrounds the plant (soil units of size 30 long ч 24 wide ч 30 deep $\mathrm{cm}$ ) was removed from each subsub-plot treatment and was placed into heavy-duty mesh bag. The roots were washed, and the live roots collected using a hose and nozzle after soil was passed through a 0.5$\mathrm{mm}^{2}$ size-opening sieve. Following drying it at $70 \pm 5^{\circ} \mathrm{C}$ to constant weight, root dry matter was determined. The root mass density $g$ root $\mathrm{cm}^{-3}$ soil was then calculated.

2.4. Statistical Analysis. The statistical analysis of the data was performed in GenStat 12th Edition VSN International Ltd (http://www.vsn-intl.com). If the variance analysis probability was less than 0.05 , mean separation was performed at the 0.05 level of significance using the least significant difference (LSD) procedure. As a factorial experiment design with block completely randomized, the physical properties of soil were analysed. The contrasts among values of averages were formulated on $P<0.05$ level of the LSD test.

\section{Results and Discussion}

3.1. Plant Height. Plant height varied significantly between different tillage systems, varieties, and nitrogen fertilization. CT resulted in increasing of plant height (139.03 and $132.78 \mathrm{~cm}$ in the QL and SHL locations, respectively), which differed significantly from other tillage practices. The lowest mean for this trait was established in NT (129.06 and $123.36 \mathrm{~cm}$ in the QL and SHL locations, respectively) (Table 3).

These results may be attributed to the fact that the conservation and conventional tillage systems encouraged the emergence and early growth of plants, as the good preparation of the seed bed for the conventional tillage system may have provided better contact of the seeds with the moist soil that is well loosened and may consequently lead to an increase in the provided moist which caused support for an earlier and better emergence compared with no-till cultivation.

Analysis of variances revealed significant differences among investigated $\mathrm{N}$ levels for plant height (Table 3). The highest average of plant height was 136.78 and $132.33 \mathrm{~cm}$ in the QL and SHL locations, respectively, for $120 \mathrm{~kg} \mathrm{~N} \mathrm{ha}^{-1}$, which is in par with $80 \mathrm{~kg} \mathrm{~N} \mathrm{ha}^{-1}$ in the QL location, which is recorded as $136.30 \mathrm{~cm}$. The lowest plant height was 129.04 and $121.78 \mathrm{~cm}$ in the QL and SHL locations, respectively, recorded under NT treatment. Nitrogen activates the meristematic tissues and thus cell division, as well as its importance in building amino acids, including tryptophan, which is the basis for building tryptophan and auxin, which has a role in cell division [14]. Similarly, Adam and Taleim [15] showed that the application of $75 \mathrm{Kg} \mathrm{N}^{-1} \mathrm{fed}^{-1}$ has increased plant height compared to other levels of nitrogen fertilizer including the controls $\left(0,25\right.$, and $\left.50 \mathrm{Kg} \mathrm{N}^{-1} \mathrm{de}^{-1}\right)$.

Sorghum varieties affected significantly plant height (Table 3). Cavire 2 recorded the tallest plant height values of 139.64 and $133.11 \mathrm{~cm}$ in the QL and SHL locations, respectively, while it was 128.69 and $122.36 \mathrm{~cm}$ in the QL and SHL locations, respectively, for Inqadh variety. The differences between varieties are often due to genetic makeup as well as the interaction between genetic makeup and environmental conditions.

Regarding the interaction between tillage systems and fertilizer levels treatments (Table 4), data showed that CT produced the tallest plant height $(142.22 \mathrm{~cm})$ under $120 \mathrm{~kg} \mathrm{~N}$ $\mathrm{ha}^{-1}$ in the QL location, which is in par with CT treatment with $80 \mathrm{~kg} \mathrm{~N} \mathrm{ha}^{-1}(142.11 \mathrm{~cm})$. The shortest plants were recorded on NT treatment under control treatment without $\mathrm{N}$ fertilizer $(124.89 \mathrm{~cm})$.

Furthermore, the interaction effect of variety with different nitrogen fertilizer levels on plant height was also significant (Table 5). Tallest plants (143.56 and $139.44 \mathrm{~cm}$ in the QL and SHL locations, respectively) were observed for Cavire 2 variety under $120 \mathrm{~kg} \mathrm{~N} \mathrm{ha}^{-1}$, while it was 122.78 and $116.33 \mathrm{~cm}$ in the QL and SHL locations, respectively, for Inqadh variety under control treatment without $\mathrm{N}$ fertilizer.

Significant interaction among tillage, varieties, and nitrogen fertilizer levels was observed for plant height in the SHL location (Table 6). The highest plants of $(146.00 \mathrm{~cm})$ were recorded for CT $\times$ Cavire $2 \times 120$, while it was 114.67 , 114.67, and $116.67 \mathrm{~cm}$ for $\mathrm{NT} \times \operatorname{Inqadh} \times 0, \mathrm{NT} \times$ Rabih $\times 0$, and $\mathrm{RT} \times \mathrm{Inqadh} \times 0$ interaction treatments, respectively.

3.2. Leaf Area. The results of the variance analysis showed that various tillage systems, varieties, and nitrogen fertilization have significantly affected the leaf area of sorghum (Table 3). Generally, in plots subject to CT technique, the leaf 


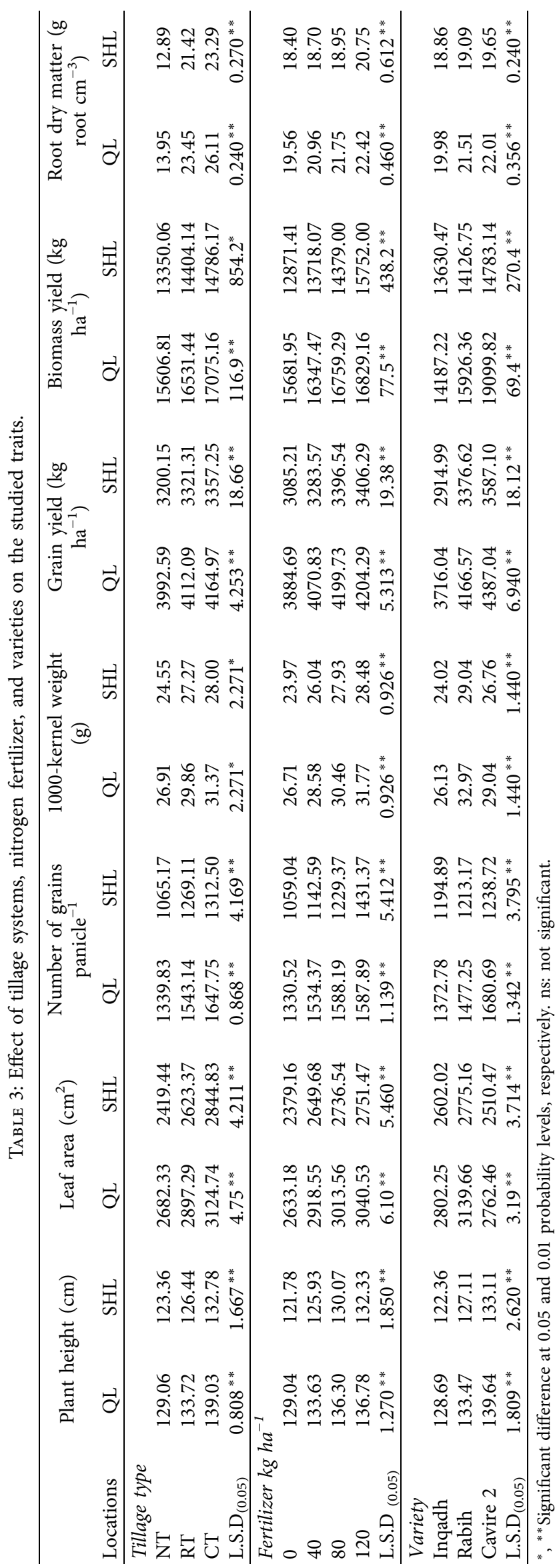


TABLE 4: Effect of tillage systems and nitrogen fertilizer interaction on the studied traits.

\begin{tabular}{|c|c|c|c|c|c|c|c|c|c|c|c|c|c|c|}
\hline \multirow[b]{2}{*}{ Locations } & \multicolumn{2}{|c|}{$\begin{array}{l}\text { Plant height } \\
(\mathrm{cm})\end{array}$} & \multicolumn{2}{|c|}{ Leaf area $\left(\mathrm{cm}^{2}\right)$} & \multicolumn{2}{|c|}{$\begin{array}{l}\text { Number of grains } \\
\text { panicle }^{-1}\end{array}$} & \multicolumn{2}{|c|}{$\begin{array}{c}\text { 1000-kernel } \\
\text { weight }(\mathrm{g})\end{array}$} & \multicolumn{2}{|c|}{$\begin{array}{c}\text { Grain yield } \\
\left(\mathrm{kg} \mathrm{ha}^{-1}\right)\end{array}$} & \multicolumn{2}{|c|}{$\begin{array}{l}\text { Biomass yield } \\
\left(\mathrm{kg} \mathrm{ha}^{-1}\right)\end{array}$} & \multicolumn{2}{|c|}{$\begin{array}{c}\text { Root } \\
\text { dry matter } \\
(\mathrm{g} \text { root } \\
\left.\mathrm{cm}^{-3}\right)\end{array}$} \\
\hline & QL & SHL & QL & SHL & QL & SHL & QL & SHL & QL & SHL & QL & SHL & QL & SHL \\
\hline \multicolumn{15}{|c|}{ Tillage $\times$ fertilizer mean } \\
\hline $\mathrm{NT} \times 0$ & 124.89 & 117.33 & & 2156.09 & 1160.78 & & 24.85 & 22.47 & & 2965.99 & & & 12.31 & 12.05 \\
\hline & & & & & & & & & & & & & 13.64 & 12.30 \\
\hline & 1 & & 2797.11 & & & & 28.06 & 6.36 & 03 & & 47 & & 14.34 & 12.57 \\
\hline $\mathrm{NT} \times 120$ & 131.67 & 27.44 & 2841.14 & & & & 28.78 & & & & & & 15.52 & 14.64 \\
\hline $\mathrm{RT} \times 0$ & 130.00 & 121.78 & 2635.87 & 2378.03 & 1363. & 1117.33 & 26.96 & 24.52 & 3903.91 & 3108. & 15824.43 & 13261 & 21.83 & 20.53 \\
\hline & & & & & & & 8 & 4 & 4100.24 & & & & 23.24 & 21.03 \\
\hline$\times 80$ & 136.11 & 129.33 & 3002.94 & 2726.06 & 1620.67 & 1278.22 & 30.75 & 27.91 & 4215.79 & 3422.24 & 17202.22 & 14548.22 & 24.35 & 21.34 \\
\hline $\mathrm{RT} \times 120$ & 136.44 & 131.11 & 3031.32 & 2742.54 & 1621.89 & 1481.78 & 32.35 & 29.51 & 4228.42 & 3438.20 & 16738.61 & 15760.22 & 24.37 & 22.80 \\
\hline $\mathrm{CT} \times 0$ & 132.22 & 126.22 & 2869.64 & & 1467.22 & & 28.32 & & 3976.17 & & & & 24.53 & 22.62 \\
\hline $\mathrm{CT} \times 40$ & 139.56 & 130.67 & 3139.59 & & 1673.11 & & 30.45 & 27.41 & 4134.45 & & 17065.50 & 13933.44 & 25.98 & 22.78 \\
\hline $\mathrm{CT} \times 80$ & 142.11 & 135.78 & 3240.63 & 2955.41 & 1726.56 & 1329.56 & 32.57 & 29.53 & 4284.37 & 3467.48 & 17347.17 & 15532.89 & 26.55 & 22.95 \\
\hline $\mathrm{CT} \times 120$ & 142.22 & 138.44 & 3249.11 & 2956.72 & 1724.11 & 1517.89 & 34.17 & 30.16 & 4264.91 & 3444.68 & 17523.76 & 16490.33 & 27.36 & 24.81 \\
\hline L.S.D ${ }_{(0.05)}$ & $1.989^{*}$ & ns & $9.76^{* *}$ & $8.730^{* *}$ & $1.819^{*}$ & $8.653^{* *}$ & $\mathrm{~ns}$ & ns & $8.537^{* *}$ & $32.12^{* *}$ & $147.1^{* *}$ & $950.1^{*}$ & ns & ns \\
\hline
\end{tabular}

*, ** Significant difference at 0.05 and 0.01 probability levels, respectively. ns: not significant.

area was greater than that reported in NT plots, (3124.74 and $2682.33 \mathrm{~cm}^{2}$, respectively, in the QL location and 2844.83 and $2419.44 \mathrm{~cm}^{2}$ in the SHL location). The enhance in flag leaf area may be associated with the decrease in bulk density rates, along with higher porosity that may facilitate nutrient movement and root proliferation and thus reaching a greater amount of nutrients necessary for growth.

Sorghum leaf area was greatest with $120 \mathrm{~kg} \mathrm{~N} \mathrm{ha}^{-1}$ (3040.53 and $2751.47 \mathrm{~cm}^{2}$ in the QL and SHL locations, respectively) and least with control treatment without $\mathrm{N}$ fertilizer (2633.18 and $2379.16 \mathrm{~cm}^{2}$ in the QL and SHL locations, respectively) (Table 3 ). Nitrogen has a great influence on cell division, so the meristematic activity of cells increases and the surface area of leaves expands accordingly [16].

The leaf area means significantly differed among the three sorghum varieties. The highest leaf area (3139.66 and $2775.16 \mathrm{~cm}^{2}$ in the QL and SHL locations, respectively) were recorded for Rabih variety, whereas the lowest one (2762.46 and $2510.47 \mathrm{~cm}^{2}$ in the QL and SHL locations, respectively) was recorded for Cavire 2 variety (Table 3 ). The variation in the leaf area among varieties may be due to different genetic characteristics of each variety.

The highest leaf area estimate for the interaction between tillage $\times$ variety was recorded for $\mathrm{CT} \times$ Rabih (3356.68 and $2982.77 \mathrm{~cm}^{2}$ in the QL and SHL locations, respectively) and the lowest leaf area was 2547.72 and $2309.26 \mathrm{~cm}^{2}$ in the QL and SHL locations, respectively, at NT $\times$ Cavire 2 interaction treatment (Table 7).

The interaction $(\mathrm{CT} \times 120)$ produced the highest leaf area (3249.11 and $2956.72 \mathrm{~cm}^{2}$ in the QL and SHL locations, respectively). Meanwhile, $\mathrm{NT} \times 0$ produced 2394.03 and $2156.09 \mathrm{~cm}^{2}$ in the QL and SHL locations, respectively (Table 4).

Furthermore, the interaction effect of varieties with different nitrogen fertilizer levels on leaf area was also significant (Table 5). The greatest leaf area (3275.49 and
$2895.66 \mathrm{~cm}^{2}$ in the QL and SHL locations, respectively) was observed for Rabih $\times 120$, while it was 2482.13 and $2253.36 \mathrm{~cm}^{2}$ in the QL and SHL locations, respectively, for Cavire $2 \times 0$ interaction treatment.

The interaction among tillage, varieties, and nitrogen fertilizer levels was significant for leaf area in the SHL location (Table 6). The highest value of $3096.37 \mathrm{~cm}^{2}$ was recorded for $\mathrm{CT} \times \mathrm{Rabih} \times 120$, while it was $2037.10 \mathrm{~cm}^{2}$ for $\mathrm{NT} \times$ Cavire $2 \times 0$.

3.3. Number of Grains per Panicle. The number of grains panicle $^{-1}$ of sorghum was significantly influenced with different tillage systems, varieties, and nitrogen fertilization.

The crop under CT recorded 3.42 and $23.22 \%$ in the QL location and 6.78 and $22.98 \%$ in the SHL location, higher number of grains panicle ${ }^{-1}$ than that of RT and NT treatments (Table 3). This might be owing to better growing conditions such as lower bulk density and higher porosity that increased root proliferation to fully exploit genetic potentiality of crop.

Different levels of nitrogen statistically affected the number of grains panicle ${ }^{-1}$ of tested sorghum varieties (Table 3). In the QL location, the number of grains panicle ${ }^{-1}$ was increased with the increase in the nitrogen level. $80 \mathrm{~kg} \mathrm{~N}$ $\mathrm{ha}^{-1}$ recorded maximum number of grains panicle ${ }^{-1}$ (1588.19) which is statistically similar to $120 \mathrm{~kg} \mathrm{~N} \mathrm{ha}^{-1}$ (1587.89) whereas control treatment $\left(0 \mathrm{~kg} \mathrm{~N} \mathrm{ha}^{-1}\right)$ recorded the lowest number of grains panicle ${ }^{-1}$ (1330.52). In the SHL location, the highest number of grains panicle ${ }^{-1}$ was 1431.37 recorded under $120 \mathrm{~kg} \mathrm{~N}$ ha $^{-1}$, while it was 1059.04 for control treatment. This result is also in line with the findings of Soleymani et al. [17], who also reported that the number of grain per panicle was increasing with the increasing level of nitrogen $200 \mathrm{~kg} \mathrm{ha}^{-1}$.

The number of grains panicle ${ }^{-1}$ was markedly influenced with sorghum varieties (Table 3 ). Among the varieties, Cavire 2 recorded significantly higher number of grains 


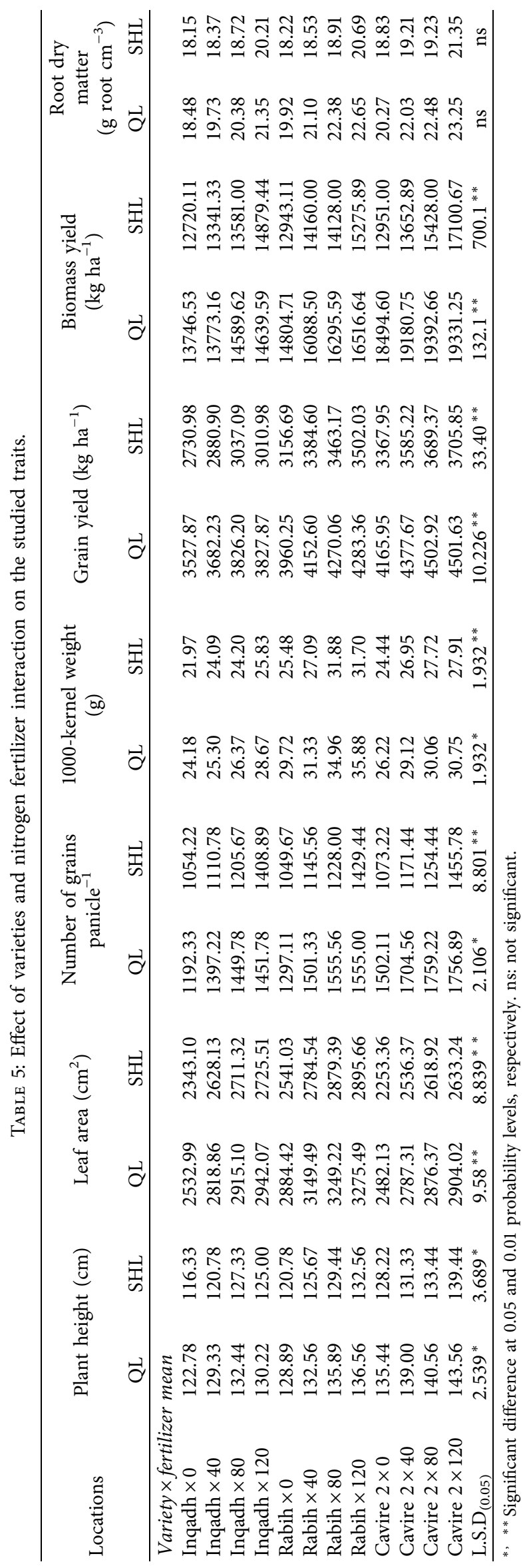




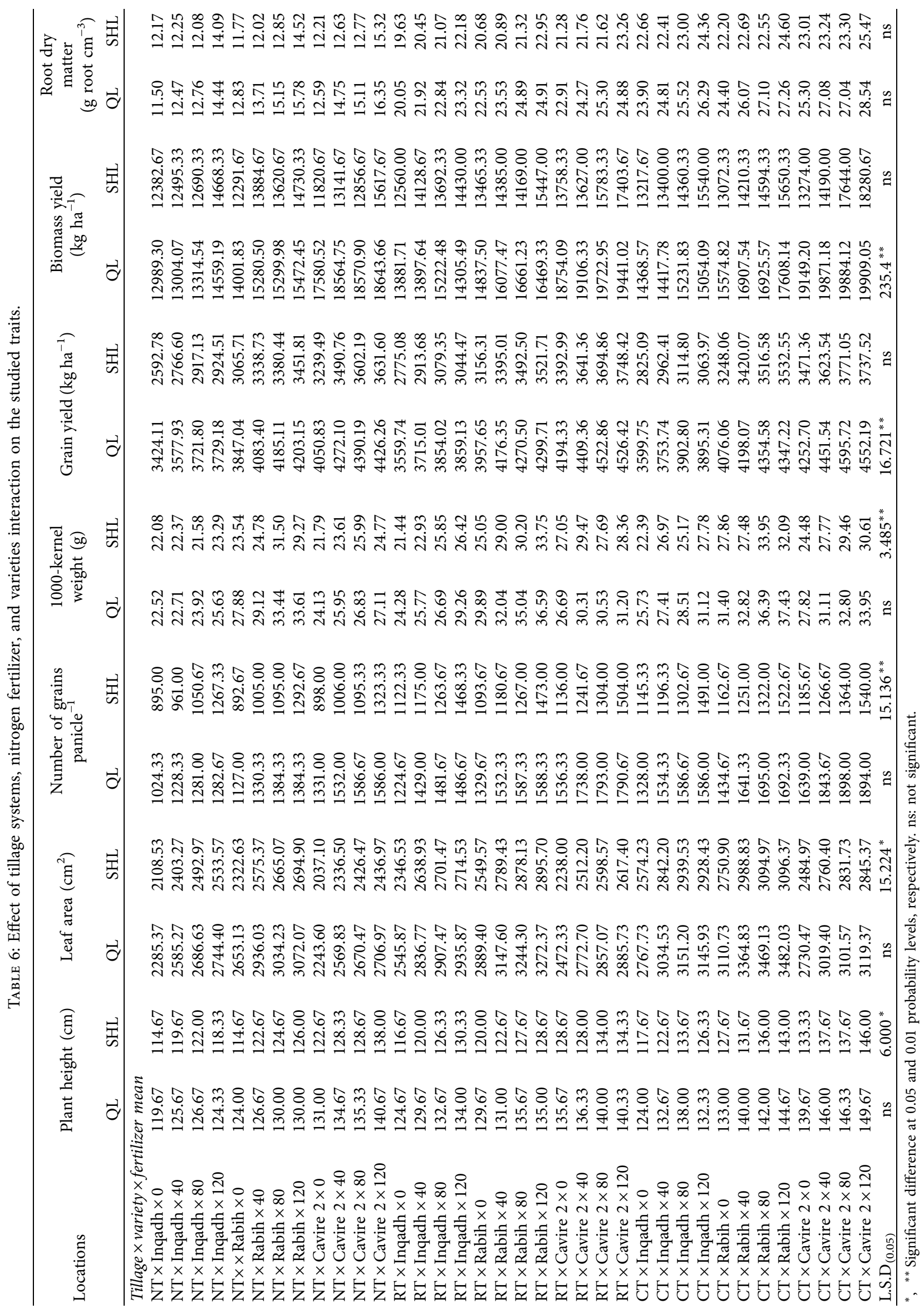


TABLE 7: Effect of tillage systems and varieties interaction on the studied traits.

\begin{tabular}{|c|c|c|c|c|c|c|c|c|c|c|c|c|c|c|}
\hline \multirow[b]{2}{*}{ Locations } & \multicolumn{2}{|c|}{$\begin{array}{l}\text { Plant height } \\
\quad(\mathrm{cm})\end{array}$} & \multicolumn{2}{|c|}{ Leaf area $\left(\mathrm{cm}^{2}\right)$} & \multicolumn{2}{|c|}{$\begin{array}{l}\text { Number of grains } \\
\text { panicle }^{-1}\end{array}$} & \multicolumn{2}{|c|}{$\begin{array}{l}\text { 1000-kernel } \\
\text { weight (g) }\end{array}$} & \multicolumn{2}{|c|}{$\begin{array}{l}\text { Grain yield } \\
\left(\mathrm{kg} \mathrm{ha}^{-1}\right)\end{array}$} & \multicolumn{2}{|c|}{$\begin{array}{c}\text { Biomass yield } \\
\left(\mathrm{kg} \mathrm{ha}^{-1}\right)\end{array}$} & \multicolumn{2}{|c|}{$\begin{array}{c}\text { Root dry } \\
\text { matter } \\
\left(\text { g root } \mathrm{cm}^{-3}\right)\end{array}$} \\
\hline & QL & SHL & QL & SHL & QL & SHL & QL & SHL & QL & SHL & QL & SHL & QL & SHL \\
\hline \multicolumn{15}{|c|}{ Tillage $\times$ variety mean } \\
\hline NT $\times$ Inqadh & 124.08 & 118.67 & 2575.42 & 2384.58 & 1204.08 & 1043.50 & 23.70 & 22.33 & 3613.25 & 2800.25 & 13466.78 & 13059.17 & 12.79 & 12.65 \\
\hline $\mathrm{NT} \times$ & 127.67 & 122.00 & 2923.87 & 2564.49 & 1306.50 & 1071.33 & 31.01 & 27.27 & 4079.67 & 3309.17 & 15013.69 & 13631.83 & 14.37 & 12.79 \\
\hline NT $\times$ Cavire 2 & 135.42 & 129.42 & 2547.72 & 2309.26 & 1508.92 & 1080.67 & 26.01 & 24.04 & 4284.84 & 3491.01 & 18339.96 & 13359.17 & 14.70 & 13.23 \\
\hline $\mathrm{RT} \times$ Inqadh & 130.25 & 123.33 & 2806.49 & 2600.37 & 1405.50 & 1257.33 & 26.50 & 24.16 & 3746.98 & 2953.14 & 14326.83 & 13702.75 & 22.03 & 20.83 \\
\hline $\mathrm{RT} \times \mathrm{Rabih}$ & 132.83 & 124.75 & 3138.42 & 2778.21 & 1509.42 & 1253.58 & 33.39 & 29.50 & 4176.05 & 3391.38 & 16011.38 & 14366.58 & 23.97 & 21.46 \\
\hline RT $\times$ Cavire 2 & 138.08 & 131.25 & 2746.96 & 2491.54 & 1714.50 & 1296.42 & 29.68 & 28.14 & 4413.24 & 3619.41 & 19256.10 & 15143.08 & 24.34 & 21.98 \\
\hline $\mathrm{CT} \times$ Inqadh & 131.75 & 125.08 & 3024.85 & 2821.10 & 1508.75 & 1283.83 & 28.19 & 25.58 & 3787.90 & 2991.57 & 14768.07 & 14129.50 & 25.13 & 23.11 \\
\hline $\mathrm{CT} \times$ Rabih & 139.92 & 134.58 & 3356.68 & 2982.77 & 1615.83 & 1314.58 & 34.51 & 30.34 & 4243.98 & 3429.31 & 16754.02 & 14381.83 & 26.21 & 23.01 \\
\hline $\mathrm{CT} \times$ Cavire 2 & 145.42 & 138.67 & 2992.70 & 2730.62 & 1818.67 & 1339.08 & 31.42 & 28.08 & 4463.04 & 3650.87 & 19703.39 & 15847.17 & 26.99 & 23.75 \\
\hline L.S.D $(0.05)$ & ns & ns & $5.76^{* *}$ & $6.040^{* *}$ & $1.978^{*}$ & $6.117^{* *}$ & ns & ns & $10.181^{* *}$ & $28.72 *$ & $133.4^{* *}$ & $843.0^{* *}$ & ns & ns \\
\hline
\end{tabular}

${ }^{*},{ }^{* *}$ Significant difference at 0.05 and 0.01 probability levels, respectively. ns: not significant.

panicle $^{-1}$ (1680.69 and 1238.72 grains panicle ${ }^{-1}$ in the QL and SHL locations, respectively) as compared to rest of the varieties, while Inqadh variety recorded 1372.78 and 1194.89 grains panicle ${ }^{-1}$ in the QL and SHL location, respectively. The differences among varieties in the studied trait are due to the difference in the genetic traits and the nature of their interaction with environmental factors (climate and soil).

The interaction of different tillage practices and varieties had statistical effect on number of grains panicle ${ }^{-1}$ (Table 7). The treatment combination CT with Cavire 2 variety recorded the maximum number of grains panicle ${ }^{-1}$ (1818.67 and 1339.08 grains panicle ${ }^{-1}$ in the QL and SHL locations, respectively), whereas the treatment combination NT with Inqadh variety recorded the lowest grains panicle ${ }^{-1}$ (1204.08 and 1043.50 grains panicle $^{-1}$ in the QL and SHL locations, respectively).

Likewise, treatment combination CT with $80 \mathrm{~kg} \mathrm{~N} \mathrm{ha}^{-1}$ in the QL location recorded the highest grains panicle ${ }^{-1}$ (1726.56). Treatment combination NT with $0 \mathrm{~kg} \mathrm{~N} \mathrm{ha}^{-1}$ recorded a lowest grains panicle ${ }^{-1}$ (1160.78). In the SHL location, the CT $\times 120$ recorded a highest value of 1517.89 . while it was 895.22 grains panicle $^{-1}$ for NT $\times 0$ interaction treatment (Table 4).

The interaction between variety and nitrogen level showed significant effect on grains panicle ${ }^{-1}$. In the QL location, Cavire $2 \times 80$ combination gave the highest grains panicle $^{-1}(1759.22)$, whereas it was 1192.33 grains panicle ${ }^{-1}$ for Inqadh $\times 0$ treatment combination (Table 5). In the SHL location, Cavire $2 \times 120$ recorded the highest value of 1455.78 grains panicle ${ }^{-1}$, while Rabih $\times 0$ recorded the lowest grains panicle ${ }^{-1}$ of 1049.67 .

The triple interaction in the SHL location was significant for grains panicle ${ }^{-1}$ as CT $\times$ Cavire $2 \times 120$ recorded the highest value of 1540.00 , while $\mathrm{NT} \times \mathrm{Rabih} \times 0$ interaction treatment recorded 892.67 grains panicle ${ }^{-1}$ (Table 6).

3.4. 1000-Grain Weight. Analysis of variance for 1000-grain weight showed that different tillage system, varieties, and nitrogen fertilization had significant effects. Mean separation (Table 3) indicated that plants under CT were significantly had a heavier 1000 -grain weight (31.37 and $28.00 \mathrm{~g}$ in the QL and SHL locations, respectively) which does not differ statistically from RT in both the locations. The NT recorded the lesser 1000-grain weight (26.91 and $24.55 \mathrm{~g}$ in the QL and SHL locations). CT systems, overall, promote root growth and access to subsoil nutrients and moisture [18], as they break through the deeper soil layer that makes the water in the lower layers of soil available to the roots. Grain weight tended to increase when water and nutrients are available. Grain weight is a component of yield, which reflects relationship between source and sink during grain filling stage.

The change in 1000-grain weight associated with $\mathrm{N}$ fertilizer varied significantly. Data recorded in the QL location for 1000-grain weight showed significant difference among $\mathrm{N}$ levels. $120 \mathrm{~kg} \mathrm{~N}^{-1}$ had the highest 1000 -grain weight $(31.77 \mathrm{~g})$, whereas control treatment without $\mathrm{N}$ fertilizer had the lowest 1000-grain weight $(26.71 \mathrm{~g})$. In the SHL location, $120 \mathrm{~kg} \mathrm{~N} \mathrm{ha}^{-1}$ had the highest value which does not differ statistically from $80 \mathrm{~kg}$ $\mathrm{N} \mathrm{ha}{ }^{-1}$ (28.48 and $27.93 \mathrm{~g}$, respectively), while it was $23.97 \mathrm{~g}$ for control treatment (Table 3 ). Nitrogen added to the soil contributes to an increase in dry matter accumulation, especially during the grain filling stage [19]. These findings agree with results of Muflahi and Basuaid [20], as they reported that the highest dose of the nitrogen application $\left(165 \mathrm{~kg} \mathrm{~N} \mathrm{ha}^{-1}\right)$ gave significantly high value of 1000 -grain weight reached at 30.278 and $34.75 \mathrm{~g}$ at the $1^{\text {st }}$ and $2^{\text {nd }}$ seasons, respectively.

Regarding varieties, the heaviest ones was Rabih recorded 32.97 and $29.04 \mathrm{~g}$ in the QL and SHL locations, respectively, while Inqadh variety recorded the lowest 1000 grain weight (26.13 and $24.02 \mathrm{~g}$ in the QL and SHL locations, respectively) (Table 3 ). The superiority of Rabih variety might be attributed to the variation in translocation rate of photosynthesis from leaves to the storing organs, i.e., the grains.

The interaction between varieties and fertilizer levels revealed a significant effect. It is observed from Table 5 that there is an increase in 1000-grain weight values for all varieties with increase in nitrogen level. In the QL location, high nitrogen level $\left(120 \mathrm{~kg} \mathrm{~N} \mathrm{ha}^{-1}\right)$ applied to Rabih variety gave high value in 1000-grain weight of $35.88 \mathrm{~g}$, whereas Inqadh variety showed low value of $24.18 \mathrm{~g}$ in control (no fertilizer). In the SHL location, Rabih $\times 80$ interaction 
treatment recorded the highest value of $31.88 \mathrm{~g}$, while it was $21.97 \mathrm{~g}$ for Inqadh $\times 0$ interaction treatment.

The triple interaction was significant at the SHL location (Table 6 ). The $\mathrm{CT} \times \mathrm{Rabih} \times 80$ recorded the highest grain weight of $33.95 \mathrm{~g}$; meanwhile, grain weight was $21.44 \mathrm{~g}$ under $\mathrm{RT} \times$ Inqadh $\times 0$ interaction treatment.

3.5. Grain Yield. The responses of the grain yield to different tillage system, varieties, and nitrogen fertilization are demonstrated in Table 3. The highest grain yield (4164.97 and $3357.25 \mathrm{~kg} \mathrm{ha}^{-1}$ in the QL and SHL locations, respectively) was obtained at CT and the lowest grain yield reading at NT $\left(3992.59\right.$ and $3200.15 \mathrm{~kg} \mathrm{ha}^{-1}$ in the QL and SHL locations, respectively) (Table 3 ). The higher yield of CT was attributed to improvement in yield components, namely, number of grains panicle ${ }^{-1}$ and 1000 -kernel weight. These results agree with previous reports that concluded CT sorghum yields were better compared with yields from RT [21].

Variance analysis showed a significant impact of nitrogen application as $120 \mathrm{~kg} \mathrm{~N} \mathrm{ha}^{-1}$; the treatment gave the highest grain yield equal to $80 \mathrm{~kg} \mathrm{~N}^{-1}$ (4204.29 and $4199.73 \mathrm{~kg} \mathrm{ha}^{-1}$, respectively, in the QL location and 3406.29 and $3396.54 \mathrm{~kg} \mathrm{ha}^{-1}$, respectively, in the SHL location), while the lowest grain yield was obtained from no fertilizer treatment (3884.69 and $3085.21 \mathrm{~kg} \mathrm{ha}^{-1}$ in the QL and SHL locations, respectively) (Table 3 ). The significant increase in grain yield at high $\mathrm{N}$ application levels could probably be attributed to higher nitrogen availability and good root growth. As stated by Showemimo [22], the use of nitrogen fertilizer increases plant vitality and dry matter weight (shoot, root, and grain). Likewise, Melaku et al. [23] stated that application of $23,41,64$, and $87 \mathrm{~kg} \mathrm{~N}^{-1}$ gave a yield increase of $40,53,62$, and $69 \%$ over the control $\left(0 \mathrm{~kg} \mathrm{~N} \mathrm{ha}^{-1}\right)$.

In the variety treatment (Table 3 ), the highest estimates were recorded by Cavire 2 (4387.04 and $3587.10 \mathrm{~kg} \mathrm{ha}^{-1}$ in the QL and SHL locations, respectively), while the lowest estimates were recorded by Inqadh $(3716.04$ and $2914.99 \mathrm{~kg}$ $\mathrm{ha}^{-1}$ in the QL and SHL locations, respectively). The superiority of this variety in grain yield may be due to the higher number of grains per panicle.

The highest estimate for the interaction between tillage $\times$ variety was recorded by CT with Cavire 2 variety (4463.04 and $3650.87 \mathrm{~kg} \mathrm{ha}^{-1}$ in the QL and SHL locations, respectively), and the lowest grain yield was 3613.25 and $2800.25 \mathrm{~kg} \mathrm{ha}^{-1}$ in the QL and SHL locations, respectively, at NT with Inqadh variety (Table 7 ).

The data listed in Table 4 show significant interactions between tillage and $\mathrm{N}$ fertilizer. CT at $80 \mathrm{~kg} \mathrm{~N}^{-1}$ recorded the highest value in the QL location of $4284.37 \mathrm{~kg} \mathrm{ha}^{-1}$ while NT with $0 \mathrm{~kg} \mathrm{~N}$ ha $^{-1}$ recorded the lowest grain yield of $3773.99 \mathrm{~kg} \mathrm{ha}^{-1}$. In the SHL location, CT $\times 80$ and $\mathrm{CT} \times 120$ recorded the highest grain yield without significant differences between them ( 3467.48 and $3444.68 \mathrm{~kg} \mathrm{ha}^{-1}$, respectively), while the lowest grain yield was $2965.99 \mathrm{~kg} \mathrm{ha}^{-1}$ under $\mathrm{NT} \times 0$ interaction treatment.

In addition, variety $\times$ fertilizer interaction was significant. Cavire 2, in the QL location, at $80 \mathrm{~kg} \mathrm{~N}^{-1}$ recorded a highest grain yield of $4502.92 \mathrm{~kg} \mathrm{ha}^{-1}$ without significant differences from Cavire $2 \times 120$ which it recorded $4501.63 \mathrm{~kg}$ $\mathrm{ha}^{-1}$, while it was $3527.87 \mathrm{~kg} \mathrm{ha}^{-1}$ for Inqadh $\times 0$. In the SHL location, Cavire $2 \times 120$ recorded a highest grain yield of $3705.85 \mathrm{~kg} \mathrm{ha}^{-1}$, which is on a par with Cavire $2 \times 80$ of $3689.37 \mathrm{~kg} \mathrm{ha}^{-1}$, while grain yield was $2730.98 \mathrm{~kg} \mathrm{ha}^{-1}$ for Inqadh $\times 0$ treatment (Table 5).

In the same direction, the results of analysis of variance indicate that all the three factors interactions affected grain yield significantly in the QL location. CT $\times$ Cavire $2 \times 80$ recorded higher a grain yield of $4595.72 \mathrm{~kg} \mathrm{ha}^{-1}$, while it was $3424.11 \mathrm{~kg} \mathrm{ha}^{-1}$ for NT $\times$ Inqadh $\times 0$ (Table 6).

3.6. Biomass Yield. Table 3 shows the average biomass yield as affected by different tillage system, varieties, and nitrogen fertilization. The results indicated that the tillage system has a significant change on the biomass yield. The CT treatment had a better biomass yield (17075.16 and $14786.17 \mathrm{~kg} \mathrm{ha}^{-1}$ in the QL and SHL locations, respectively) compared with NT (15606.81 and $13350.06 \mathrm{~kg} \mathrm{ha}^{-1}$ in the QL and SHL locations, respectively). CT does not defer significantly from RT in the SHL location. This can be attributed to increased soil loosening, reduced bulk density, and increased porosity (Table 8), facilitated root movement, and increased proliferation and access to greater depths, which increases water absorption, especially during periods of low moisture, as well as increased nutrients movement with movement of water and increased absorption of nutrients from the tilled soil section, thus increasing dry matter production. A connected study carried out by Serme [24] on growth and yield of sorghum under different conservation tillage reported greater biomass yield for conventional tillage compared with no tillage.

Significant effects among nitrogen fertilization levels were reported for biomass yield. Table 3 shows that, in the QL location, $120 \mathrm{~kg} \mathrm{~N} \mathrm{ha}^{-1}$ produced the highest biomass yield of $16829.16 \mathrm{~kg} \mathrm{ha}^{-1}$, which in turn did not differ significantly from $80 \mathrm{~kg} \mathrm{~N}^{-1}\left(16759.29 \mathrm{~cm}^{2}\right)$. The control treatment without $\mathrm{N}$ fertilizer recorded $15681.95 \mathrm{~kg} \mathrm{ha}^{-1}$. In the SHL location, the highest biomass yield was $15752.00 \mathrm{~kg}$ $\mathrm{ha}^{-1}$ recorded for $120 \mathrm{~kg} \mathrm{~N} \mathrm{ha}^{-1}$, while it was 13078.48 and $13511.00 \mathrm{~kg} \mathrm{ha}^{-1}$ for control treatment without $\mathrm{N}$ fertilizer and $80 \mathrm{~kg} \mathrm{~N} \mathrm{ha}{ }^{-1}$, respectively, without any significant difference between them. The increase in biological yield was due to better growth and development of plants under adequate supply of $\mathrm{N}$ during growth stages. Nitrogen is necessary in the growth and development of essential plant tissues and cells. Nitrogen insufficiency considerably diminishes the nutrient uptake through roots and nutrient provided to shoots; in this manner, root development considerably impacts the shoot development [25]. This result is in agreement with the finding of Almodares et al. [26], who recorded the highest biomass with the maximum nitrogen level of $200 \mathrm{~kg} \mathrm{~N}^{-1}$ urea over other levels of nitrogen $\left(50,100\right.$, and $150 \mathrm{~kg}$ urea ha $\left.{ }^{-1}\right)$.

The data also indicated that Cavire 2 variety showed higher biomass yield of 19099.82 and $14783.14 \mathrm{~kg} \mathrm{ha}^{-1}$ in the QL and SHL locations, respectively, while Inqadh variety showed lower value of 14187.22 and $13630.47 \mathrm{~kg} \mathrm{ha}^{-1}$ in the 
TABLE 8: Bulk density and porosity at the two experimental locations in the soil profile for the investigated tillage systems.

\begin{tabular}{|c|c|c|c|c|}
\hline \multirow[b]{2}{*}{ Treatments } & \multicolumn{2}{|c|}{ QL location } & \multicolumn{2}{|c|}{ SHL location } \\
\hline & $\begin{array}{l}\text { Bulk density } \\
\mathrm{kg} \mathrm{m}^{-3}\end{array}$ & $\begin{array}{c}\text { Porosity } \\
\%\end{array}$ & $\begin{array}{l}\text { Bulk density } \\
\mathrm{kg} \mathrm{m}^{-3}\end{array}$ & $\begin{array}{c}\text { Porosity } \\
\%\end{array}$ \\
\hline NT & 1483.34 & 42.69 & 1493.42 & 42.53 \\
\hline CT & 1363.01 & 44.82 & 1377.11 & 44.56 \\
\hline RT & 1404.31 & 44.09 & 1428.88 & 43.66 \\
\hline L.S.D $(0.05)$ & $43.67^{* *}$ & $0.798^{* *}$ & $38.93^{* *}$ & $0.695^{* *}$ \\
\hline 0_10 & 1387.14 & 44.42 & 1405.63 & 44.08 \\
\hline $10 \_20$ & 1410.56 & 43.98 & 1424.61 & 43.73 \\
\hline $20 \_30$ & 1410.62 & 43.95 & 1432.42 & 43.57 \\
\hline 30_40 & 1459.23 & 43.12 & 1469.88 & 42.95 \\
\hline L.S.D $(0.05)$ & $50.42^{*}$ & ns & $44.96^{*}$ & ns \\
\hline NT $\times 0-10$ & 1480.64 & 42.74 & 1497.35 & 42.46 \\
\hline $\mathrm{NT} \times 10-20$ & 1496.69 & 42.47 & 1498.13 & 42.45 \\
\hline $\mathrm{NT} \times 20-30$ & 1468.15 & 42.95 & 1477.04 & 42.8 \\
\hline $\mathrm{NT} \times 30-40$ & 1487.88 & 42.62 & 1501.17 & 42.4 \\
\hline $\mathrm{CT} \times 0-10$ & 1320.4 & 45.62 & 1341.21 & 45.22 \\
\hline $\mathrm{CT} \times 10-20$ & 1352.82 & 44.99 & 1361.85 & 44.82 \\
\hline $\mathrm{CT} \times 20-30$ & 1362.3 & 44.8 & 1378.13 & 44.51 \\
\hline $\mathrm{CT} \times 30-40$ & 1416.51 & 43.86 & 1427.24 & 43.67 \\
\hline $\mathrm{RT} \times 0-10$ & 1360.38 & 44.9 & 1378.31 & 44.55 \\
\hline $\mathrm{RT} \times 10-20$ & 1382.16 & 44.47 & 1413.87 & 43.92 \\
\hline $\mathrm{RT} \times 20-30$ & 1401.4 & 44.1 & 1442.1 & 43.39 \\
\hline $\mathrm{RT} \times 30-40$ & 1473.3 & 42.88 & 1481.23 & 42.78 \\
\hline L.S.D ${ }_{(0.05)}$ & ns & ns & ns & ns \\
\hline
\end{tabular}

*, ${ }^{* *}$ Significant difference at 0.05 and 0.01 probability levels, respectively. ns: not significant.

QL and SHL locations, respectively (Table 3). The variation of varieties in this trait is due to the difference in their genetic characteristics.

Among interactions, the highest biomass yield estimate for the interaction between tillage and variety was recorded by CT with Cavire 2 variety of 19703.39 and $15847.17 \mathrm{~kg} \mathrm{ha}^{-1}$ in the QL and SHL locations, respectively, while NT with Inqadh variety recorded 13466.78 and $13059.17 \mathrm{~kg} \mathrm{ha}^{-1}$ in the QL and SHL locations, respectively. The CT $\times$ Cavire 2 interaction treatment did not defer significantly from RT $\times$ Cavire 2 interaction treatment in the SHL location (Table 7).

The interaction $(\mathrm{CT} \times 120)$ produced the highest biomass yield $\left(17523.76\right.$ and $16490.33 \mathrm{~kg} \mathrm{ha}^{-1}$ in the QL and SHL locations, respectively). Meanwhile, $\mathrm{NT} \times 0$ produced 14857.22 and $12202.56 \mathrm{~kg} \mathrm{ha}^{-1}$ in the QL and SHL locations, respectively (Table 4 ).

The interaction between varieties and fertilizer revealed significant effect. Table 5 shows an increase in the biomass yield with an increase in the nitrogen level. In the QL location, the nitrogen level $\left(80 \mathrm{~kg} \mathrm{~N} \mathrm{ha}^{-1}\right)$ applied to Cavire 2 variety gave higher value of biomass yield $19392.66 \mathrm{~kg} \mathrm{ha}^{-1}$ that did not defer significantly from Cavire $2 \times 120$ $\left(19331.25 \mathrm{~kg} \mathrm{ha}^{-1}\right)$, whereas, Inqadh variety showed low value in control (no fertilizer) treatment $13746.53 \mathrm{~kg} \mathrm{ha}^{-1}$. In the SHL location, the Cavire $2 \times 120$ interaction treatment recorded a highest biomass yield of $17100.67 \mathrm{~kg} \mathrm{ha}^{-1}$, while it was 12720.11 and $13341.33 \mathrm{~kg} \mathrm{ha}^{-1}$ for Inqadh $\times 0$ and Inqadh $\times 80$ interaction treatments, respectively without significant difference between them.
Significant interaction effect was observed among tillage, variety, and nitrogen fertilizer levels for biomass yield in the QL location. The highest biomass yield (19909.05 $\mathrm{kg} \mathrm{ha}^{-1}$ ) was recorded for $\mathrm{CT} \times$ Cavire $2 \times 120$, which is in par with $\mathrm{CT} \times$ Cavire $2 \times 80, \mathrm{CT} \times$ Cavire $2 \times 80$, and $\mathrm{RT} \times$ Cavire $2 \times 80$, while it was $12989.30 \mathrm{~kg} \mathrm{ha}^{-1}$ for $\mathrm{NT} \times \operatorname{Inqadh} \times 0$ interaction treatment (Table 6).

3.7. Root Dry Matter. The tillage method was significantly affected the sorghum average root dry matter across the entire root sampling profile, decreasing in the order $\mathrm{CT}>\mathrm{RT}>\mathrm{NT}$ (Table 3 ). This was probably owing to better growth environment caused by reduced bulk density and increased porosity that might provide better soil-moisture regimes with the respective treatment.

The root dry matter under $\mathrm{N}$ fertilizer treatments was significantly higher than that under control treatment without $\mathrm{N}$ fertilizer (Table 3). The highest value in the QL

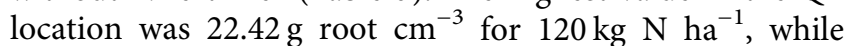
control treatment recorded $19.56 \mathrm{~g}$ root $\mathrm{cm}^{-3}$. In the SHL location, $\mathrm{N}$ treatment of $120 \mathrm{~kg} \mathrm{~N} \mathrm{ha}^{-1}$ recorded the highest value of $20.75 \mathrm{~g}$ root $\mathrm{cm}^{-3}$, while the lowest was $18.40 \mathrm{~g}$ root $\mathrm{cm}^{-3}$ for control treatment without significant differences from 40 and $80 \mathrm{~kg} \mathrm{~N} \mathrm{ha}^{-1}$. Such impact of nitrogen on root dry matter might be credited to its function in constructing up metabolites and activation of enzymes that accompanies with accumulation of carbohydrates, which translocated from leaves to growing roots [27]. It was reported that, as nitrogen level increased, root dry weight and the amount of seminal roots of wheat have increased [28].

Root dry matter in each location also differed significantly among variety treatments. At the QL location, root dry matter of Cavire 2 was $2.32 \%$ and $10.16 \%$ higher than that of Rabih and Inqadh respectively. At the SHL location, root dry matter of Cavire 2 was $2.93 \%$ and $4.19 \%$ higher than that of Rabih and Inqadh, respectively. There were no statistical differences between Rabih and Inqadh variety $(\mathrm{Ta}-$ ble 3 ). The variation in root dry matter among varieties might be due to different genetic characteristics of each variety.

3.8. Bulk Density and Porosity. Table 8 shows the effects of the tillage system and depths to each experimental location on bulk density and porosity through the $0-40 \mathrm{~cm}$ soil profile. Statistical significance among tillage systems in bulk density was observed, and the order NT $>$ RT $>$ CT was followed. At QL experimental location, there were no significant differences between RT and CT. This might be due to loosening of the soil by the plow as well as the difference in the geometry of the tillage machine used in each system. Significant differences in bulk density between conventional tillage and no tillage have been documented on a clay loam soil under a corn-soybean rotation in the long-term (29 years) [29].

The soil bulk density varied significantly with soil depth. The highest increase at the QL location from 10-20 to $30-40 \mathrm{~cm}$ without significant differences among them while lowest bulk density was observed at $0-10 \mathrm{~cm}$ layer. In the 
SHL location, the largest increase was at $30-40$ and $20-30 \mathrm{~cm}$ layers, while it decreases for $0-10,10-20$, and $20-30 \mathrm{~cm}$ layers without significant differences among them. The increase in bulk density with increasing depth may be due to the weight of the upper soil layers and the effect of their pressure downward, which leads to the convergence of soil particles from each other and increases the density.

Porosity across the $0-40 \mathrm{~cm}$ soil profile at different tillage practices varied significantly as it decreased in the order $\mathrm{CT}>\mathrm{RT}>\mathrm{NT}$. The greatest porosity was observed in the QL location for CT and RT without significant differences between them while lowest value recorded for NT. In the SHL location, soil porosity of CT was 2.06 and $4.77 \%$ higher than those of RT and NT. Conducting the tillage process led to loosening and pulverizing the soil and increasing the size of the interstitial spaces between the particles, thus increasing the porosity compared to no tillage, in which the particles were more close and coherent, thus increasing its compression and less free pores.

\section{Conclusion}

The plant height, leaf area, yield and yield components, root dry matter and biomass yield of sorghum were significantly affected by various tillage practices, varieties, and nitrogen fertilizer levels. The CT $\times$ Cavire $2 \times 80$ produced the highest grain yield. Meanwhile, the combination of $\mathrm{CT} \times$ Cavire $2 \times 120$ produced the maximum biomass yield. The application of nitrogen fertilizer enhanced the growth and yield of sorghum compared with the control. Increasing $\mathrm{N}$ levels significantly increased studied traits. Nitrogen amounts of 80 and $120 \mathrm{~kg} \mathrm{ha}^{-1}$ were found to be superior compared with other levels and were in par with each other for the majority of traits. There were significant differences among sorghum varieties. Cavire 2 variety had maximum grain yield. Tillage treatments studied had a significant effect as it increased the porosity and reduced the bulk density in the soil surface layer. Generally, the results of this study show that tillage, soil fertility management, and variety selection cannot be ignored if the productivity of sorghum has to be improved in semi-arid areas in the short term.

\section{Data Availability}

The data used to support the findings of this study are available from the corresponding author upon request.

\section{Conflicts of Interest}

The authors declare that there are no potential conflicts of interest.

\section{Acknowledgments}

The authors express thanks to the University of Basrah, College of Agriculture, for providing the laboratory for conducting this experiment.

\section{References}

[1] S. Higashida and M. Yamagami, "Effects of deep plowing with concomitant application of farm yard manure on the productivity of arable crops," Bulletin of Hokkaido Prefectural Agricultural Experiment Stations, vol. 84, pp. 55-64, 2003, Japan.

[2] X. Wang, H. Wu, K. Dai et al., "Tillage and crop residue effects on rainfed wheat and maize production in northern China," Field Crops Research, vol. 132, pp. 106-116, 2012.

[3] D. R. Coventry, R. S. Poswal, A. Yadav et al., "Effect of tillage and nutrient management on wheat productivity and quality in Haryana, India," Field Crops Research, vol. 123, no. 3, pp. 234-240, 2011.

[4] M. P. Sharma, P. Bal, and J. P. Gupta, "Long term effects of chemical; fertilizers on rice-wheat productivity," Annals of Agricultural Research, vol. 24, no. 1, pp. 91-94, 2003.

[5] Y. Malhi, C. Doughty, and D. Galbraith, "The allocation of ecosystem net primary productivity in tropical forests," Philosophical Transactions of the Royal Society B: Biological Sciences, vol. 366, no. 1582, pp. 3225-3245, 2011.

[6] G. J. Bouyoucos, "Hydrometer method improved for making particle size analysis of soils," Agronomy Journal, vol. 27, pp. 738-741, 1965.

[7] J. M. Bremner, "Nitrogen-total," SSSA Book Series, Methods Of Soil Analysi, vol. 5, pp. 1085-1121, 1996.

[8] S. R. Olsen and L. E. Sommers, "Phosphorus," in Methods of Soil Analysis, A. L. Page et al., Ed., American Society of Agronomy, Madison, WI, USA, 2nd edition, 1982.

[9] G. R. Blake and K. H. Hartge, "Bulk density," Methods of Soil Analysis: Part 1 Physical and Mineralogical Methods, vol. 5, pp. 363-375, 1986.

[10] A. L. Flint and L. E. Flint, "2.2 particle density," Methods of Soil Analysis: Part 4 Physical Methods, vol. 5, pp. 229-240, 2002.

[11] U. R. Bishnoi, D. A. Mays, and M. T. Fabasso, "Response of no-till and conventionally planted grain sorghum to weed control method and row spacing," Plant and Soil, vol. 129, no. 2, pp. 117-120, 1990.

[12] W. Bayu, N. F. G. Rethman, and P. S. Hammes, "Growth and yield compensation in sorghum (Sorghum bicolorL. Moench) as a function of planting density and nitrogen fertilizer in semi-arid areas of northeastern Ethiopia," South African Journal of Plant and Soil, vol. 22, no. 2, pp. 76-83, 2005.

[13] W.-Z. Qi, H.-H. Liu, P. Liu et al., "Morphological and physiological characteristics of corn (Zea mays L.) roots from cultivars with different yield potentials," European Journal of Agronomy, vol. 38, pp. 54-63, 2012.

[14] M. B. Jackson, Interactions between Nitrogen and Growth Regulators in the Control of Plant Development, British Plant Growth Regulator Group, Wantage, UK, 1st edition, 1983.

[15] A. H. M. Adam and M. A. Taleim, "Effect of nitrogen fertilizer on some attributes of sorghum grown in saline soil under irrigation," Journal of Agronomy Research, vol. 1, no. 2, pp. 12-17, 2018.

[16] C. Joly, "Mineral fertilizers: plant nutrient content, formulation and efficiency," FAO Fertilizer and Plant Nutrition Bulletin (FAO), vol. 12, pp. 267-278, 1995.

[17] A. Soleymani, M. H. Shahrajabian, and L. Naranjani, "The effect of plant density and nitrogen fertilization on yield, yield components and grain protein of grain sorghum," Journal of Food, Agriculture and Environment, vol. 9, no. 3, pp. 244-246, 2011. 
[18] W. Mupangwa, S. Twomlow, and S. Walker, "Reduced tillage, mulching and rotational effects on maize (Zea mays L.), cowpea (Vigna unguiculata (Walp) L.) and sorghum (Sorghum bicolor L. (Moench)) yields under semi-arid conditions," Field Crops Research, vol. 132, pp. 139-148, 2012.

[19] S. L. Tisdale, W. L. Nelson, J. D. Beton, and J. L. Havlin, Soil Fertility and Fertilizers, 5th Prentice Hall, Upper Saddle River, NY, USA, 1993.

[20] A. A. M. Muflahi and A. S. Basuaid, "Effect of nitrogen fertilizer and its application efficiency on two local sorghum cultivars sorghum bicolor L. Moench," Journal of Agricultural Science, vol. 9, no. 4, pp. 236-241, 2017.

[21] H. R. Elramlawi, H. I. Mohammed, A. W. Elamin, O. A. Abdallah, and A. A. A. M. Taha, "Adaptation of sorghum (Sorghum bicolor L. Moench) crop yield to climate change in eastern dryland of Sudan," in Handbook of Climate Change ResilienceSpringer International Publishing Cham, Cham, Switzerland, 2018.

[22] F. A. Showemimo, "Relationships between sources and levels of nitrogen fertilization and the control of striga hermonthica in Sorghum," International Journal of Agricultural Research, vol. 2, no. 2, pp. 170-174, 2007.

[23] N. D. Melaku, W. Bayu, F. Ziadat et al., "Effect of nitrogen fertilizer rate and timing on sorghum productivity in Ethiopian highland Vertisols," Archives of Agronomy and Soil Science, vol. 64, no. 4, pp. 480-491, 2018.

[24] I. Serme, Growth And Yield of Sorghum under Different Conservation Tillage and Water and Nutrient Management Practices in the South Sudan Zone Of Burkina faso (Doctoral Dissertation), Kwame Nkrumah University of science and technology, Kumasi, Ghana, 2015.

[25] Z. P. Shangguan, M. A. Shao, S. J. Ren, L. M. Zhang, and Q. Xue, "Effect of nitrogen on root and shoot relations and gas exchange in winter wheat," Botanical Bulletin of Academia Sinica, vol. 45, no. 1, pp. 49-54, 2004.

[26] A. Almodares, M. Jafarinia, and M. R. Hadi, "The effects of nitrogen fertilizer on chemical compositions in corn and sweet sorghum," Agriculture and Environment Science, vol. 6, pp. 441-446, 2009.

[27] M. N. Kashem, Q. A. Khaliq, M. A. Karim, A. J. M. S. Karim, and M. R. Islam, "Effect of nitrogen and potassium on dry matter production and yield in tropical sugar beet in Bangladesh," Pakistan Sugar Journal, vol. 30, no. 2, p. 6, 2015.

[28] Y. L. Liang and P. Y. Chen, "Adjustment of physiological characters of root systems of wheat by soil moisture, nitrogen and phosphorus," Acta Phytoecol Sin, vol. 20, no. 3, pp. 255-262, 1996.

[29] X. H. Shi, X. M. Yang, C. F. Drury, W. D. Reynolds, N. B. McLaughlin, and X. P. Zhang, "Impact of ridge tillage on soil organic carbon and selected physical properties of a clay loam in southwestern Ontario," Soil and Tillage Research, vol. 120, pp. 1-7, 2012. 